\title{
Illegal Fishing Dari Perspektif Kitab Undang-Undang Hukum Acara Pidana (Kuhap)
}

\author{
${ }^{1}$ Yuheni Tarida Kendal, ${ }^{2}$ Ummi Kalsum, ${ }^{2}$ Zul Akli \\ Email : yuhenitarida@gmail.com \\ 1 Alumni Fakultas Hukum Universitas Malikussaleh \\ 2 Dosen Fakultas Hukum Universitas Malikussaleh
}

\begin{abstract}
The problem of illegal fishing is a serious problem that must be considered, because it has significantly reduced productivity and catch and has damaged the ecosystem and marine biological resources. Illegal fishing has been specifically regulated in the Fisheries Law but this regulation deviates from the Criminal Procedure Law. This study aims to determine and explain the application of the Criminal Procedure Code against illegal fishing and to find out and explain the obstacles and solutions in the application of the Criminal Procedure Code against illegal fishing. This study uses a descriptive normative legal research method. The approach used is the statutory approach, carried out by reviewing all laws and regulations related to legal issues related to illegal fishing. Based on the research results, it is known that the application of the Criminal Procedure Code against illegal fishing, namely the arrest can be made for a maximum of one day. The deadline for settlement of a criminal case is 400 days to complete a case starting from investigation to the decision of the Supreme Court. Whereas in the Fisheries Law, the arrest of ships and / or people suspected of committing violations on the ZEEI is a maximum of seven days. The time limit for settling illegal fishing cases is quite short, namely 140 days to settle a case starting from investigation to the decision of the Supreme Court. The obstacles in the application of the Criminal Procedure Code consist of the authority to investigate, the length of time of arrest, and the period of detention. The enactment of the lex specialis derogate legi generalis principle has become a solution in the application of Criminal Procedure Law. With the provisions of this principle, illegal fishing is prioritized using the Fisheries Law procedural law and if it is not regulated in the Fisheries Law, then the Criminal Procedure Code is used. It is recommended that law enforcers revise the Fisheries Law so that the settlement of illegal fishing crimes can be done optimally and law enforcers should prioritize rehabilitating and restoring a situation rather than imprisoning the perpetrators of illegal fishing and to the community so that legal norms can be adjusted so that carried out properly by the community itself, lest the community act arbitrarily such as bribing.
\end{abstract}

Key words: Illegal Fishing, Criminal Procedure Code 


\section{A. PENDAHULUAN}

Indonesia adalah negara kepulauan, hal ini dikarenakan wilayah Indonesia terdiri dari pulau-pulau. Arti dari negara kepulauan berdasarkan Undang-Undang Republik Indonesia Nomor 32 Tahun 2014 Tentang Kelautan pada Pasal 1 ayat (5) dapat diartikan suatu negara yang seluruhnya terdiri atas satu atau lebih kepulauan dan dapat mencakup pulau-pulau lain. Yang mempunyai 17.504 pulau dengan garis pantai panjangnya $95.181 \mathrm{~km}$. Berdasarkan Konvensi Hukum Laut Internasional (UNCLOS) 1982, Indonesia mempunyai kedaulatan terhadap wilayah perairan seluas 3,2 juta $\mathrm{km}^{2}$ yang terdiri atas perairan kepulauan seluas 2,9 juta $\mathrm{km}^{2}$ dan laut teritorial seluas 0,3 juta $\mathrm{km}^{2}$.(Winawarti, 2016)

Di wilayah perairan laut Indonesia yang luas juga terkandung sumber daya perikanan yang besar. Sehingga mendorong banyak nelayan asing maupun lokal melakukan kegiatan pemanfaatan sumber daya perikanan di perairan Indonesia dengan cara tidak sah. Misalnya penangkapan ikan secara tidak sah, sepanjang Januari 2021 sebanyak 9 kapal yang terdiri dari 8 kapal ikan asing dan 1 kapal ikan dalam negeri melakukan penangkapan ikan secara tidak sah.(Rinovsky, 2021)

Tindak pidana illegal Fishing adalah tindakan menangkap ikan dengan menggunakan surat penangkapan ikan dengan izin palsu, tidak dilengkapi dengan surat izin penangkapan ikan (SIPI), menggunakan alat tangkap terlarang, dan menangkap ikan dengan jenis dan ukuran yang tidak sesuai dengan izin.(Tunggal, 2013)

Penangkapan ikan secara ilegal ini telah merugikan negara secara finansial, karena telah ikut menurunkan produktivitas dan hasil tangkapan secara signifikan.(Simela, 2012) Dampak lain dari illegal fishing adalah kerusakan ekosistem dan sumber hayati laut. Banyak terumbu karang yang rusak dan hancur akibat penangkapan ikan yang dilakukan menggunakan alat dan bahan yang dilanggar. Penggunaan bahan-bahan kimia dan alat berbahaya yang tidak ramah lingkungan hanya akan membunuh biota laut, yang pada akhirnya ikan-ikan yang seharusnya tidak untuk ditangkap ikut mati dan populasi ikan akan menjadi sedikit karena penggunaan alat tangkap ikan dalam skala besar yang dapat mengakibatkan keberlangsungan perikanan terganggu. Kegiatan illegal fishing tersebut dilakukan oleh nelayannelayan asing dari negara-negara tetangga di kawasan yang memasuki perairan Indonesia secara melawan aturan hukum. (Solihin, 2010)

Dewasa ini dalam UndangUndang Nomor 45 Tahun 2009 perubahan atas Undang-Undang Nomor 31 Tahun 2004 tentang Perikanan telah memuat regulasi baik mengenai hukum acara pidana maupun tindak pidana perikanan sebagai suatu kebijakan dalam penanggulangan illegal fishing yang akan menjadi landasan dalam kebijakan aplikasi maupun eksekusi yang dibentuk dengan tujuan agar 
terciptanya efektifitas dan efisiensi penegakan hukum di bidang perikanan.(Rudiansyah, 2015) Hukum acara dalam penyidikan, penuntutan maupun persidangan pada pengadilan perikanan dilakukan menurut Kitab Undang-Undang Hukum Acara Pidana (KUHAP) kecuali telah ditentukan secara khusus dalam Undang-Undang Nomor 45 Tahun 2009 perubahan atas Undang-Undang Nomor 31 Tahun 2004 tentang Perikanan. Tindak pidana perikanan juga telah mendapatkan legitimasi dalam Bab XV, yaitu dalam Pasal 84 sampai dengan Pasal 105 Undang-Undang Nomor 45 Tahun 2009 perubahan atas Undang-Undang Nomor 31 Tahun 2004 tentang Perikanan.

Pasal 73B ayat (3) UndangUndang Nomor 45 Tahun 2009 perubahan atas Undang-Undang Nomor 31 Tahun 2004 tentang Perikanan menyebutkan Penyidikan tindak pidana di bidang perikanan di wilayah pengelolaan perikanan Negara Republik Indonesia dilakukan oleh Penyidik Pegawai Negeri Sipil Perikanan, Penyidik Perwira TNI AL, dan/atau Penyidik Kepolisian Negara Republik Indonesia. Penyidikan perikanan dalam menjalankan tugasnya mempunyai kewenangan untuk melakukan penahanan terhadap orang dan barang. Untuk kepentingan proses penyidikan perkara, penyidik perikanan mempunyai waktu penahanan terhadap tersangka paling lama 20 hari, apabila masih diperlukan untuk kepentingan yang belum selesai, pemeriksaan penahanan dapat diperpanjang 10 hari.
Pasal 76 ayat (7) UndangUndang Nomor 45 Tahun 2009 perubahan atas Undang-Undang Nomor 31 Tahun 2004 tentang Perikanan menyebutkan Penuntutan terhadap tindak pidana di bidang perikanan dilakukan oleh penuntut umum yang ditetapkan oleh Jaksa Agung. Penuntut umum diberi wewenang melakukan penahanan terhadap tersangka selama 10 hari untuk kepentingan penuntutan dan apabila penahanan masih diperlukan guna kepentingan pemeriksaan yang belum selesai, penahanan dapat diperpanjang oleh ketua pengadilan negeri yang berwenang paling lama 10 hari.

$$
\text { Pasal } 81 \text { ayat (2) Undang- }
$$

Undang Nomor 45 Tahun 2009 perubahan atas Undang-Undang Nomor 31 Tahun 2004 tentang Perikanan Pengadilan perikanan berwenang memeriksa, mengadili, dan memutuskan perkara tindak pidana di bidang perikanan yang terjadi di wilayah pengelolaan perikanan Negara Republik Indonesia, baik yang dilakukan oleh warga negara Indonesia maupun warga negara asing. Untuk kepentingan pemeriksaan di persidangan pengadilan perikanan, hakim diberi wewenang untuk menahan terdakwa selama 20 hari, penahanan ini dilakukan sejak pengadilan perikanan menerima pelimpahan berkas perkara terdakwa dari penuntut umum. Apabila penahanan masih diperlukan guna kepentingan pemeriksaan yang belum selesai, penahanan dapat diperpanjang paling lama 10 hari. 
Kitab Undang-Undang Hukum Acara Pidana (KUHAP) adalah dasar bagi aparat penegak hukum seperti kepolisian, kejaksaan, dan pengadilan untuk melaksanakan wewenangnya. Kitab ini mengatur tentang penyidikan, penuntutan, mengadili, dan hal lain yang menjadi prosedur dari tindak pidana yang diatur oleh Kitab UndangUndang Hukum Pidana (KUHP).

Pasal 1 ayat (1) Kitab UndangUndang Hukum Acara Pidana menyatakan Penyidik adalah pejabat polisi negara Republik Indonesia atau pejabat pegawai negeri sipil tertentu yang diberi wewenang khusus oleh undang-undang untuk melakukan penyidikan. Disamping yang diatur dalam Pasal 1 ayat (1) Kitab UndangUndang Hukum Acara Pidana, terdapat juga Pasal 10 Kitab Undang-Undang Hukum Acara Pidana, yang mengatur tentang adanya penyidik pembantu disamping penyidik.(Harahap 2011) Untuk kepentingan penyidikan, penyidik atau penyidik pembantu atas perintah penyidik berwenang melakukan penahanan selama 20 hari, apabila masih diperlukan untuk kepentingan yang belum selesai, pemeriksaan penahanan dapat diperpanjang 40 hari.

Pasal 1 ayat (7) Kitab UndangUndang Hukum Acara Pidana menyatakan Penuntutan adalah tindakan penuntut umum untuk melimpahkan perkara pidana ke pengadilan negeri yang berwenang dalam hal dan menurut cara yang diatur dalam undang-undang ini dengan permintaan supaya diperiksa dan diputus oleh hakim di sidang pengadilan. Penuntut umum juga berwenang melakukan penahanan selama 20 hari, apabila masih diperlukan untuk kepentingan yang belum selesai, pemeriksaan penahanan dapat diperpanjang 40 hari.

Pasal 1 ayat (9) Kitab UndangUndang Hukum Acara Pidana menyebutkan Mengadili adalah serangkaian tindakan hakim untuk menerima, memeriksa dan memutus perkara pidana berdasarkan asas bebas, jujur, dan tidak memihak di sidang pengadilan dalam hal dan menurut cara yang diatur dalam undang-undang. Untuk kepentingan pemeriksaan hakim di sidang pengadilan berwenang melakukan penahanan selama 20 hari, jika diperlukan untuk kepentingan yang belum selesai, pemeriksaan penahanan dapat diperpanjang 40 hari.

Dari penjelasan diatas, dapat disimpulkan bahwa ternyata hukum acara illegal fishing masih menyimpang dengan Kitab Undang-Undang Hukum Acara Pidana baik itu penyidikan, penuntutan, dan wewenang pengadilan dalam mengadili. Sehingga penanganan tindak pidana di bidang perikanan pada saat ini belum berjalan secara maksimal dan mengalami berbagai hambatan dalam penyelesaiannya.

Waktu penahanan bagi penyidik perikanan maksimal 30 hari, waktu penahanan tersebut lebih singkat dibandingkan ketentuan Pasal 24 Kitab Undang-Undang Hukum Acara Pidana karena untuk perkara pidana pada umumnya penahanan dengan waktu paling lama 60 hari. Waktu penahanan dalam penuntutan maksimal 20 hari, 
waktu penahanan tersebut lebih singkat dibandingkan ketentuan Pasal 24 Kitab Undang-Undang Hukum Acara Pidana karena untuk perkara pidana pada umumnya penahanan dengan waktu paling lama 60 hari. Sehingga konsekuensinya penuntut umum harus dapat bekerja cepat untuk membuat surat dakwaan untuk kepentingan pelimpahan berkas ke pengadilan. Waktu penahanan dalam pemeriksaan di persidangan pengadilan perikanan maksimal 30 hari, waktu penahanan tersebut juga lebih singkat dibandingkan ketentuan Pasal 24 Kitab Undang-Undang Hukum Acara Pidana karena untuk perkara pidana pada umumnya penahanan dengan waktu paling lama 60 hari. Sehubungan dengan hal latar belakang diatas, maka penulis tertarik melakukan penelitian yang lebih mendalam tentang Illegal Fishing Dari Perspektif Kitab UndangUndang Hukum Acara Pidana (KUHAP). Adapun yang menjadi permasalahan dalam penelitian ini adalah bagaimana penerapan Kitab Undang-Undang Hukum Acara Pidana (KUHAP) terhadap tindak pidana illegal fishing dan apakah hambatan dan solusi dalam penerapan Kitab UndangUndang Hukum Acara Pidana (KUHAP) terhadap tindak pidana illegal fishing. Tujuan dari penelitian ini untuk mengetahui dan menjelaskan penerapan Kitab Undang-Undang Hukum Acara Pidana (KUHAP) terhadap tindak pidana illegal fishing dan ntuk mengetahui dan menjelaskan hambatan dan solusi dalam penerapan Kitab Undang-Undang Hukum Acara
Pidana (KUHAP) terhadap tindak pidana illegal fishing.

\section{B. IDENTIFIKASI MASALAH}

Jenis penelitian yang digunakan dalam penelitian ini adalah penelitian hukum normatif, penelitian hukum normatif pada hakikatnya mengkaji hukum yang di konsepkan sebagai norma atau kaidah yang berlaku dalam masyarakat, dan menjadi acuan perilaku setiap orang. Penelitian ini menggunakan metode penelitian hukum normatif yang bersifat deskriptif. Dengan pendekatan yang digunakan adalah pendekatan perundangundangan, dilakukan dengan menelaah semua undang-undang dan regulasi yang bersangkut paut dengan isu hukum yang berkaitan dengan illegal fishing.

\section{Penerapan Kitab Undang-Undang Hukum Acara Pidana (Kuhap) Terhadap Tindak Pidana Illegal Fishing}

\section{Penerapan Kitab Undang-Undang Hukum Acara Pidana}

Kitab Undang-Undang Hukum Acara Pidana mencakup seluruh prosedur acara pidana, yaitu mulai dari proses tingkat penyelidikan dan penyidikan, penuntutan sampai pemeriksaan di pengadilan dan pelaksanaan putusan hakim (eksekusi). Kitab Undang-Undang Hukum Acara Pidana mengatur bagaimana negara melalui alat-alatnya melaksanakan haknya untuk memidana dan menjatuhkan pidana, jadi berisi acara 
pidana. Kedudukan Kitab UndangUndang Hukum Acara Pidana sebagai lex generalis yang mengatur hal-hal yang belum diatur dalam UndangUndang Perikanan sebagai lex specialis. Jadi, sepanjang belum diatur di dalam Undang-Undang Perikanan masih tetap berlaku peraturan umum yang ada di dalam Kitab Undang-Undang Hukum Acara Pidana. ${ }^{1}$

\section{Perbandingan}

Dalam Kitab Undang-Undang Hukum Acara Pidana mengatur mengenai penyelidikan, sedangkan dalam Undang-Undang Perikanan tidak mengatur mengenai penyelidikan, tetapi mengatur mengenai penyidikan. Penyidikan dalam Undang-Undang Perikanan dilakukan oleh Penyidik Pegawai Negeri Sipil Perikanan, Penyidik Perwira TNI AL, dan/atau Penyidik Kepolisian Negara Republik Indonesia. Penyidik dapat melakukan koordinasi dalam penanganan illegal fishing. Koordinasi diperlukan selain untuk kelancaran pelaksanaan tugas penyidik, juga dimaksudkan untuk memperlancar komunikasi dan tukar menukar data, informasi, serta hal lain yang diperlukan dalam rangka efektivitas dan efisiensi penanganan dan/atau penyelesaian tindak pidana perikanan. Dalam rangka mendukung kelancaran pelaksanaan tugas penyidikan terhadap tindak pidana dibidang perikanan, maka telah dibentuk antara lain: a. Forum Koordinasi Penanganan Tindak Pidana di Bidang Perikanan

Forum ini dibentuk berdasarkan Peraturan Menteri Kelautan dan Perikanan Nomor: PER.11/MEN/2006 tanggal 16 Pebruari 2006, yang mempunyai tugas mengkoordinasikan kegiatan penyidikan tindak pidana di bidang perikanan yang dilaksanakan oleh masing-masing instansi terkait agar efektif, efisien, dan memenuhi rasa keadilan. Dalam melaksanakan tugasnya Forum Koordinasi Penanganan Tindak Pidana di Bidang Perikanan menyelenggarakan fungsi:

a) Koordinasi kegiatan penyidikan tindak pidana di bidang perikanan;

b) Identifikasi jenis, modus operandi, volume, dan penyebaran paktik-praktik tindak pidana di bidang perikanan;

c) Penetapan jenis tindak pidana di bidang perikanan yang diprioritaskan untuk diproses secara bertahap;

d) Penyuluhan dan pembinaan kepada masyarakat untuk mencegah terjadinya tindak pidana di bidang perikanan;

e) Analisis, identifikasi dan pengukuran signifakasi tindak pidana di bidang perikanan secara periodik;

f) Perancangan bentuk-bentuk koordinasi kegiatan pemberantasan tindak pidana di bidang perikanan;

\footnotetext{
${ }^{1}$ Gatot Supramono, Op.Cit, hlm. 151.
} 
g) Perumusan dan pemutakhiran strategi pemberantasan tindak pidana di bidang perikanan;

h) Pemantauan dan penyajian laporan pelaksanaan pemberantasan tindak pidana di bidang perikanan;

i) Pengkajian dan evaluasi efektivitas strategi pemberantasan tindak pidana di bidang perikanan secara berkelanjutan.

b. Pembentukan Tim Teknis Penanganan Tindak Pidana di Bidang Perikanan

Pembentukan ini berdasarkan Keputusan Menteri Kelautan dan Perikanan Republik Indonesia selaku Ketua Forum Koordinasi Penanganan Tindak Pidana di Bidang Perikanan Nomor: KEP.04/MEN/2007 tanggal 17 Januari 2007.

\section{c. Badan Koordinasi Keamanan Laut \\ Badan Koordinasi Keamanan} Laut (Bakorkamla), adalah lembaga non struktural yang berkedudukan di bawah dan bertanggung jawab kepada Presiden. Bakorkamla dibentuk berdasarkan Peraturan Presiden Republik Indonesia Nomor: 81 Tahun 2005 tanggal 29 Desember 2005, yang mempunyai tugas mengkoordinasikan penyusunan kebijakan dan pelaksanaan kegiatan operasi keamanan laut secara terpadu. Dalam melaksanakan tugasnya, Bakorkamla menyelenggarakan fungsi: a) Perumusan dan penetapan kebijakan umum di bidang keamanan laut

b) Koordinasi kegiatan dalam pelaksanaan tugas di bidang keamanan laut yang meliputi kegiatan penjagaan, pengawasan, pencegahan/penindakan pelanggaran hukum, pengamanan pelayaran, pengamanan aktifitas masyarakat dan pemerintah di wilayah perairan Indonesia;

c) Pemberian dukungan teknis dan administrasi di bidang keamanan laut secara terpadu.

Penyidik dalam Kitab UndangUndang Hukum Acara Pidana adalah pejabat polisi negara Republik Indonesia, penyidik pegawai negeri sipil yang diberi wewenang khusus oleh undang-undang untuk melakukan penyidikan terhadap tindak pidana tertentu. Penyidik pegawai negara sipil dalam menjalankan tugas keberadaannya di bawah koordinasi dan pengawasan pejabat polisi negara Republik Indonesia. Dalam Kitab Undang-Undang Hukum Acara Pidana juga mengatur mengenai penyidik pembantu yang mempunyai wewenang seperti penyidik, kecuali mengenai penahanan yang wajib diberikan dengan pelimpahan wewenang dari penyidik.

Perintah penahanan yang diberikan oleh penyidik dalam Kitab Undang-Undang Hukum Acara Pidana berlaku paling lama 60 (enam puluh) hari, setelah waktu 60 (enam puluh) hari 
tersebut, penyidik harus sudah mengeluarkan tersangka dari tahanan demi hukum. Dalam Undang-Undang Perikanan untuk kepentingan penyidikan, penyidik dapat menahan tersangka paling lama 30 (tiga puluh) hari, setelah waktu 30 (tiga puluh) hari tersebut, penyidik harus sudah mengeluarkan tersangka dari tahanan demi hukum.

Perintah penahanan yang diberikan oleh penuntut umum dalam Kitab Undang-Undang Hukum Acara Pidana berlaku paling lama 50 (lima puluh) hari, setelah waktu 50 (lima puluh) hari tersebut, penuntut umum harus sudah mengeluarkan tersangka dari tahanan demi hukum. Dalam Undang-Undang Perikanan untuk kepentingan penuntutan, penuntut umum berwenang melakukan penahanan atau penahanan lanjutan selama 20 (dua puluh) hari.

Dalam Kitab Undang-Undang Hukum Acara Pidana Hakim pengadilan negeri yang mengadili perkara guna kepentingan pemeriksaan berwenang mengeluarkan surat perintah penahanan untuk paling lama 90 (sembilan puluh) hari. Setelah waktu 90 (sembilan puluh) hari walaupun perkara tersebut belum diputus, terdakwa harus sudah dikeluarkan dari tahanan demi hukum. Dalam UndangUndang Perikanan untuk kepentingan pemeriksaan, hakim di sidang pengadilan berwenang menetapkan penahanan selama 30 (tiga puluh) hari.

Dalam Kitab Undang-Undang
Hukum Acara Pidana Hakim

pengadilan tinggi yang mengadili perkara guna kepentingan pemeriksaan banding berwenang mengeluarkan surat perintah penahanan untuk paling lama 90 (sembilan puluh) hari. Setelah waktu 90 (sembilan puluh) hari walaupun perkara tersebut belum diputus, terdakwa harus sudah dikeluarkan dari tahanan demi hukum. Dalam Undang-Undang Perikanan untuk kepentingan pemeriksaan, hakim di sidang pengadilan tinggi berwenang menetapkan penahanan selama 30 (tiga puluh) hari.

Dalam Kitab Undang-Undang Hukum Acara Pidana Hakim Mahkamah Agung yang mengadili perkara guna kepentingan pemeriksaan kasasi berwenang mengeluarkan surat perintah penahanan untuk paling lama 110 (seratus sepuluh) hari. Setelah waktu 110 (seratus sepuluh) hari walaupun perkara tersebut belum diputus, terdakwa harus sudah dikeluarkan dari tahanan demi hukum. Dalam Undang-Undang Perikanan untuk kepentingan pemeriksaan, hakim di sidang Mahkamah Agung berwenang menetapkan penahanan selama 30 (tiga puluh) hari.

\section{Kewenangan Penyidik Tindak Pidana Illegal Fishing}

Masalah kewenangan penyidik sangat penting, bila dikaitkan dengan penegakan hukum, karena penegak hukum dipastikan berwenang dalam melakukan penyidikan terhadap suatu 
kasus yang terjadi di laut sampai penyidik itu sendiri menyerahkan berkas perkara kepada Kejaksaan Negeri sebagai penuntut umum. Untuk tidak menimbulkan salah pengertian antar penegak hukum, maka penerapan kewenangan ini perlu disadari bersama, bahwa penegak hukum bukan sematamata untuk mencari kepentingan sendiri, tapi pola tindak dan pola laku tiap aparat penegak hukum harus mempunyai prinsip yaitu hukum di seluruh wilayah Republik Indonesia dalam wadah Negara Kesatuan Republik Indonesia harus ditegakkan. Dalam undang-undang sudah jelas memberikan kepastian hukum bagi setiap pelanggaran di laut, maka upaya menciptakan rasa keadilan harus ditegakkan dengan tidak mengurangi kewenangan masing-masing aparat penegak hukum di perairan Indonesia, sebagai pejabat penyidik tindak pidana perikanan khususnya tindak pidana illegal fishing. Hal ini untuk menghindari adanya tumpang tindih kewenangan dan pola pikir sektoral dari masing-masing aparat.

Ketentuan tentang penyidikan terhadap tindak pidana perikanan diatur dalam Pasal 73 Undang-Undang Nomor 45 Tahun 2009 Perubahan Atas Undang-Undang Nomor 31 Tahun 2004 tentang Perikanan, yaitu terdiri dari Penyidik Pegawai Negeri Sipil Perikanan, Penyidik Perwira TNI AL, dan Pejabat Polisi Negara Republik Indonesia. Perlu diketahui bahwa dengan adanya tiga institusi penyidik dan tiga pejabat yang berwenang mengangkat yaitu penyidik Perwira TNI
AL diangkat oleh Panglima TNI, penyidik Polri diangkat oleh Kapolri dan PPNS Perikanan diangkat berdasarkan usul kementerian yang bersangkutan diangkat oleh Menteri Hukum dan HAM.

\section{Analisis}

Berdasarkan hasil kajian di atas maka proses penahanan dalam Kitab Undang-Undang Hukum Acara Pidana pada tahap penyidik hanya berlaku paling lama 20 (dua puluh) hari. Jangka waktu ini apabila diperlukan guna kepentingan pemeriksaan yang belum selesai, dapat diperpanjang oleh penuntut umum yang berwenang untuk paling lama 40 (empat puluh) hari. Setelah waktu 60 (enam puluh) hari tersebut, penyidik harus sudah mengeluarkan tersangka dari tahanan demi hukum.

Pada tahap penuntut umum penahanan hanya berlaku paling lama 20 (dua puluh) hari. Jangka waktu ini apabila diperlukan guna kepentingan pemeriksaan yang belum selesai, dapat diperpanjang oleh ketua pengadilan negeri yang berwenang untuk paling lama 30 (tiga puluh) hari. Setelah waktu 50 (lima puluh) hari tersebut, penuntut umum harus sudah mengeluarkan tersangka dari tahanan demi hukum.

Hakim pengadilan negeri juga berwenang mengeluarkan surat perintah penahanan untuk paling lama 30 (tiga puluh) hari. Jangka waktu ini apabila diperlukan guna kepentingan pemeriksaan yang belum selesai, dapat diperpanjang oleh ketua pengadilan 
negeri yang bersangkutan untuk paling lama 60 (enam puluh) hari. Setelah waktu 90 (sembilan puluh) hari walaupun perkara tersebut belum diputus, terdakwa harus sudah dikeluarkan dari tahanan demi hukum.

Hakim pengadilan tinggi yang mengadili perkara guna kepentingan pemeriksaan banding juga berwenang mengeluarkan surat perintah penahanan untuk paling lama 30 (tiga puluh) hari. Jangka waktu ini apabila diperlukan guna kepentingan pemeriksaan yang belum selesai, dapat diperpanjang oleh ketua pengadilan tinggi yang bersangkutan untuk paling lama 60 (enam puluh) hari. Setelah waktu 90 (sembilan puluh) hari walaupun perkara tersebut belum diputus, terdakwa harus sudah dikeluarkan dari tahanan demi hukum.

Hakim Mahkamah Agung yang mengadili perkara guna kepentingan pemeriksaan kasasi juga berwenang mengeluarkan surat perintah penahanan untuk paling lama 50 (lima puluh) hari. Jangka waktu ini apabila diperlukan guna kepentingan pemeriksaan yang belum selesai, dapat diperpanjang oleh Ketua Mahkamah Agung untuk paling lama 60 (enam puluh) hari. Setelah waktu 110 (seratus sepuluh) hari walaupun perkara tersebut belum diputus, terdakwa harus sudah dikeluarkan dari tahanan demi hukum.

Dalam hukum acara UndangUndang Perikanan perintah penahanan yang diberikan oleh penyidik terhadap tersangka paling 20 (dua puluh) hari, apabila masih diperlukan untuk kepentingan yang belum selesai, pemeriksaan penahanan dapat diperpanjang 10 (sepuluh) hari. Setelah waktu 30 (tiga puluh) hari tersebut, penyidik harus sudah mengeluarkan tersangka dari tahanan demi hukum.

Perintah penahanan diberikan oleh penuntut umum paling lama 10 (sepuluh) hari dan apabila penahanan masih diperlukan guna kepentingan pemeriksaan yang belum selesai, penahanan dapat diperpanjang oleh ketua pengadilan negeri yang berwenang paling lama 10 (sepuluh hari) hari. Setelah waktu 20 (dua puluh) hari tersebut, penuntut umum harus sudah mengeluarkan tersangka dari tahanan demi hukum.

Untuk kepentingan pemeriksaan di persidangan pengadilan perikanan, hakim diberi wewenang menetapkan penahanan selama 20 (dua puluh) hari. Apabila penahanan masih diperlukan guna kepentingan pemeriksaan yang belum selesai, penahanan dapat diperpanjang paling lama 10 (sepuluh) hari.

Untuk kepentingan pemeriksaan, hakim di sidang pengadilan tinggi berwenang menetapkan penahanan selama 20 (dua puluh) hari. Apabila penahanan masih diperlukan guna kepentingan pemeriksaan yang belum selesai, penahanan dapat diperpanjang paling lama 10 (sepuluh) hari.

Untuk kepentingan pemeriksaan, hakim di sidang mahkamah agung berwenang menetapkan penahanan selama 20 (dua puluh) hari. Apabila penahanan masih diperlukan guna kepentingan pemeriksaan yang belum 
selesai, penahanan dapat diperpanjang paling lama 10 (sepuluh) hari.

Namun dalam ketentuan hukum acara Undang-Undang Perikanan mengikuti asas lex spesialis derogate lex generalis yang mengandung makna bahwa aturan hukum yang khusus akan mengesampingkan aturan hukum yang umum. Sehingga dapat disimpulkan ketika teerdapat suatu aturan yang tidak diatur dalam Undang-Undang Perikanan maka yang digunakan adalah Kitab Undang-Undang Hukum Acara Pidana. Maka dalam ketentuan tersebut sudah jelas terhadap pelanggaran ikan yang dilakukan di perairan Indonesia ternyata masih menggunakan hukum acara Undang-Undang Perikanan.

\section{Penerapan Kitab Undang-Undang} Hukum Acara Pidana (KUHAP) Terhadap Tindak Pidana Illegal Fishing

Kedudukan Kitab UndangUndang Hukum Acara Pidana sebagai lex generalis yang mengatur hal-hal yang belum diatur dalam UndangUndang Perikanan sebagai lex specialis. Jadi, sepanjang belum diatur di dalam Undang-Undang Perikanan masih tetap berlaku peraturan umum yang ada di dalam Kitab Undang-Undang Hukum Acara Pidana. Penerapan Kitab Undang-Undang Hukum Acara Pidana dimulai dari penyelidikan. Dalam hal penyidikan telah dimulai, maka penyidik segera memberitahukan hal itu kepada pihak kejaksaan (dibuatkan SPDP). Untuk keperluan penyidikan, penyidik melakukan hal-hal sebagai berikut:

$\begin{array}{ll}\text { 1. } & \text { Penangkapan } \\ \text { 2. } & \text { Penahanan } \\ \text { 3. } & \text { Penggeledahan } \\ \text { 4. } & \text { Penyitaan }\end{array}$

\section{KESIMPULAN}

Berdasarkan analisis tersebut diatas, dapat ditarik simpulan yaitu pertama, Penerapan Kitab UndangUndang Hukum Acara Pidana terhadap tindak pidana illegal fishing yaitu dalam Kitab Undang-Undang Hukum Acara Pidana mengatur penangkapan yang dapat dilakukan untuk paling lama satu hari. Batas waktu penyelesaian perkara tindak pidana dalam Hukum Acara Pidana yaitu 400 hari untuk menyelesaikan suatu perkara mulai dari penyidikan sampai dengan putusan Mahkamah Agung. Sedangkan di dalam UndangUndang Perikanan mengatur penangkapan terhadap kapal dan/atau orang-orang yang diduga melakukan pelanggaran di Zona Ekonomi Eksklusif Indonesia tidak boleh melebihi jangka waktu tujuh hari. Batas waktu penyelesaian perkara tindak pidana perikanan cukup singkat, yaitu 140 hari untuk menyelesaikan suatu perkara mulai dari penyidikan sampai dengan putusan Mahkamah Agung. Sehingga tidak sinkronisasi dalam penerapan Hukum Acara Pidana dan UndangUndang Perikanan terhadap tindak pidana illegal fishing. Kedua, Hambatan dan solusi dalam penerapan Kitab Undang-Undang Hukum Acara Pidana merupakan hambatan dari 
materi perundang-undangan yang berasal substansi hukum, menyangkut peraturan perundang-undangan yang tidak konsisten, sehingga membawa pengaruh dalam pelaksanaan penegakan hukum. Hambatanhambatan tersebut terdiri dari kewenangan penyidikan, lama penangkapan, dan jangka waktu penahanan. Berlakunya asas lex specialis derogate legi generalis telah menjadi solusi dalam penerapan Kitab Undang-Undang Hukum Acara Pidana terhadap tindak pidana illegal fishing. Dengan ketentuan asas ini maka terhadap tindak pidana illegal fishing diutamakan menggunakan hukum acara Undang-Undang Perikanan dan apabila tidak diatur dalam UndangUndang Perikanan, maka digunakan Undang-Undang Hukum Acara Pidana, sehingga tidak terjadi tumpang tindih dalam penyelesaian tindak pidana illegal fishing.

\section{DAFTAR PUSTAKA}

Abdul Firmansyah, Pencurian Ikan Oleh Kapal Asing Di Wilayah Teritorial Indonesia Dalam Perspektif Hukum Positif Di Indonesia, Jurnal Lex et Societatis, Volume. 4, No. 1, Januari 2016.

Abdul Qodir Jaelani Dan Udiyo Basuki, Illegal Unreported and Unregulated (IUU) Fishing: Upaya Mencegah dan Memberantas Illegal Fishing dalam Membangun Poros Maritim Indonesia, Jurnal Supremasi Hukum, Volume. 3, No. 1, Juni 2014.
Adi Susanto, Hubungan antara Penegakan Hukum di Laut dan Ketahanan Nasional, Forum Hukum, Volume. 4, No. 4, 2007.

Afrianto Sagita, Optimalisasi Pengadilan Perikanan Dalam Penegakan Hukum Tindak Pidana Perikanan Di Perairan Indonesia, Jurnal Hukum Dan Peradilan, Volume 6, No. 2, Februari 2017.

Agus Irawan, Penegakan Hukum Pidana terhadap Tindak Pidana Perikanan, https://www.neliti.com/publications/286 640/penegakan-hukum-pidana-terha dap-tindak-pidana-perikanan, akses tanggal 1 Mei 2018.

Ahmad Jazuli, Penyelesaian Konflik Penodaan Agama dalam Perspektif Hukum Pidana di Indonesia, Jurnal Penelitian Hukum De Jure, Volume. 17, No. 3, September 2017.

Akhmad Fauzi, 2007, Kebijakan Perikanan Dan Kelautan, Jakarta: Gramedia.

Akhmad Solihin, 2008, Pemberantasan Illegal Fishing Menurut Hukum Internasional dan Implementasinya Dalam Peraturan PerundangUndangan Nasional, Tesis, Bandung: Universitas Padjadjaran.

Supriadi and Alimuddin, 2001, Hukum Perikanan Indonesia, Jakarta: Sinar Grafika.

Teguh Prasetyo, 2010, Hukum Pidana, Jakarta: Rajawali Pers.

Tommy Sitohang, Masalah Illegal Unregulated Unreported Fishing dan Penanggulangannya melalui pengadilan perikanan, Jurnal Keadilan, No. 2, April 2006. 
Tri Andrisma, 2007, Hukum Pidana, Bandar Lampung: Universitas Lampung.

Vedro Imanuel, Pembaharuan Hukum Dalam Hal Kriminalisasi Dan Sanksi Pidana Bagi Pelaku Tindak Prostitusi, https://www.coursehero.com/file /86892488/FRDMdocx/, akses tanggal 20 Maret 2020.

Yosep Aliyin, Pengertian dan Asas Hukum Acara Pidana, https://yosepali yinsh.blogspot.com/2012/11/pengertian -dan-asas-hukum-

acarapidana_2020.html, akses tanggal 25 November 2012. 